\title{
Analisis Multilevel Kemiskinan Rumah Tangga Pertanian di Provinsi Sulawesi Selatan Tahun 2020
}

\author{
Volandio Ardhian Rastantra \\ Badan Pusat Statistik Kabupaten Bulukumba \\ J1. Jendral Ahmad Yani No. 18 Bulukumba, Sulawesi Selatan 92512 \\ e-mail: ardhian.rastantra@bps.go.id
}

\begin{abstract}
ABSTRAK
Sulawesi Selatan sebagai daerah agraris memiliki potensi sektor pertanian yang besar. Namun, masih terdapat beberapa permasalahan yang dihadapi oleh rumah tangga pertanian seperti rendahnya kesejahteraan petani dan tingginya tingkat kemiskinan penduduk yang bekerja di sektor pertanian. Terdapat perbedaan yang terlihat dalam persentase penduduk miskin yang bekerja di sektor pertanian pada masingmasing kabupaten/kota. Adanya struktur hierarki individu dan wilayah pada data yang digunakan, maka pemodelan harus mengakomodasi korelasi individu di dalam satu wilayah supaya estimasi parameter akan lebih efisien. Metode regresi multilevel sesuai dengan data berstruktur hierarki, selain itu dapat menjelaskan adanya keragaman dalam model. Karena variabel dependen berupa data kategorik dengan dua kategorik, maka penelitian ini menggunakan regresi multilevel logistik biner untuk menganalisis variabel rumah tangga dan wilayah yang memengaruhi kemiskinan rumah tangga pertanian serta mengetahui variasi wilayah terhadap kemiskinan. Dari penelitian diperoleh hasil bahwa variabel rumah tangga yang signifikan memengaruhi kemiskinan rumah tangga pertanian antara lain pendidikan KRT, jenis kelamin KRT, jumlah ART, tipe daerah, kepemilikan lahan, dan akses layanan keuangan. Jika dilihat dari variabel kabupaten/kota, IPM signifikan memengaruhi kemiskinan rumah tangga pertanian. Sebesar 11,56 persen keragaman status kemiskinan rumah tangga pertanian di Provinsi Sulawesi Selatan disebabkan oleh perbedaan karakteristik antar kabupaten/kota.
\end{abstract}

Kata kunci : Kemiskinan, Rumah Tangga Pertanian, Regresi Multilevel, Provinsi Sulawesi Selatan.

\section{ABSTRACT}

South Sulawesi as agricultural area has large potential for agricultural sector. However there are still some problems faced by agricultural households such as low welfare of farmers and high level of poverty of the population working in agricultural sector. There is difference in the percentage of poor working in agricultural sector in each district/city. There is hierarchical structure of individuals and region in data used, then modelling must accommodate individual correlations in area so parameter estimation be more efficient. Multilevel regression method fit data with hierarchical structure, besides that it can explain diversity in model. Because dependent variable is categorical data with two categories, this study uses binary multilevel logistic regression to analyze household and regional variables that affect agricultural households poverty and determine regional variations in poverty. From the research, it is found that household variables have a significant effect on agricultural household poverty include household head education, gender of household head, number of household members, type of area, land ownership, and access to financial services. From regional variable, HDI significantly affects agricultural household poverty. 11.56 percent of the diversity in the poverty status of agricultural households in South Sulawesi Province is caused by differences in characteristics between districts/cities.

Keywords : Poverty, Agricultural Household, Multilevel Regression, South Sulawesi Province.

\section{PENDAHULUAN}

Sebagai daerah agraris, Sulawesi Selatan merupakan lumbung pangan beras nasional dan wilayah penghasil komoditas penting sektor pertanian lainnya. Sektor pertanian memiliki peranan penting dalam pembangunan di Sulawesi Selatan. Peranan tersebut digambarkan melalui sumbangan lapangan usaha pertanian terhadap Produk Domestik Regional Bruto (PDRB) Sulawesi Selatan sebesar 21,70 persen pada tahun 2020 (BPS, 2020). Angka tersebut menjadikan pertanian memiliki share PDRB terbesar dibandingkan lapangan usaha lain seperti industri, konstruksi, dan perdagangan.

Volandio Ardhian Rastantra/

J Statistika Vol. 14, No. 2, (2021) 
Berdasarkan hasil Sakernas Agustus 2020, sebanyak 1,93 juta penduduk bekerja di sektor pertanian atau sekitar 39,78 persen dari jumlah penduduk bekerja di Sulawesi Selatan. Hal itu menjadikan sektor pertanian unggul dibandingkan sektor lain dalam penyerapan tenaga kerja. Namun, dibalik potensi sektor pertanian yang begitu besar, terdapat beberapa masalah yang dihadapi oleh pekerja sektor pertanian di Sulawesi Selatan. Salah satunya adalah masih rendahnya Nilai Tukar Petani (NTP) Provinsi Sulawesi Selatan pada tahun 2020, yaitu sebesar 96,97. Hal tersebut menunjukkan bahwa petani mengalami defisit dan mengindikasikan rendahnya kesejahteraan petani.

Masalah lain yang dihadapi adalah tingginya tingkat kemiskinan pada rumah tangga pertanian. Pada tahun 2020 terdapat 30,46 persen penduduk usia 15 tahun ke atas berstatus miskin dan bekerja di sektor pertanian (BPS, 2020). Lebih besar dibandingkan penduduk yang bekerja di sektor selain pertanian dan berstatus miskin sekitar 9 persen. Selain itu, persentase penduduk miskin di masing-masing kabupaten/kota pada sektor pertanian menunjukkan adanya perbedaan yang cukup terlihat. Hal ini membuat dugaan adanya pengaruh wilayah terhadap status kemiskinan rumah tangga pertanian.

Struktur data hierarki berasal dari populasi yang memiliki tingkatan dan berkelompok dalam satu unit. Data yang berstruktur secara hierarki memiliki efek dari kelompok yang membawahi unit penelitian (Hox, 2010). Adanya struktur hierarki individu dan wilayah pada data yang digunakan, maka pemodelan harus mengakomodasi korelasi individu di dalam satu wilayah supaya estimasi parameter akan lebih efisien. Goldstein (1995) memperkenalkan analisis regresi multilevel sebagai pengembangan untuk mengatasi masalah yang disebabkan oleh data yang memiliki struktur hierarki.

Model regresi multilevel adalah bagian dari Generalized Linear Mixed Model (GLMM) dimana dalam persamaan modelnya menggabungkan fixed effect dan random effect. Model ini pada dasarnya merupakan versi bertingkat model regresi berganda untuk menganalisis data dengan struktur hierarki (Hox, 2010). Metode ini sering digunakan dalam kasus-kasus sosial terutama untuk data berstruktur hierarki yang sering ditemukan pada penelitian survei dimana penarikan sampel dilakukan secara bertahap (cluster sampling). Selain itu, metode multilevel juga mampu menjelaskan keragaman dalam model.

Volandio Ardhian Rastantra/

J Statistika Vol. 14, No. 2, (2021)
Hox (2010) menyebutkan bahwa terdapat dua bentuk dasar model multilevel, yaitu model dengan random intercept dan model dengan random slope. Model random intercept memodelkan dimana setiap kelompok memiliki intercept yang berbeda, sedangkan model random slope memodelkan variabel independen pada level yang rendah sebagai random effect sehingga tiap kelompok memiliki garis kemiringan yang berbeda.

Dalam model regresi multilevel jika variabel respon memiliki distribusi binomial, maka dalam pendugaan parameter menggunakan fungsi hubungan logit $(\ln \{\pi /(1-\pi)\})$ sehingga dinamakan model regresi multilevel logistik biner. Penelitian ini menggunakan model regresi multilevel logistik biner random intercept dengan asumsi pengaruh masing-masing variabel adalah sama pada level kabupaten/kota. Selain itu, estimasi model random slope kurang dapat dipercaya menurut Hox (2010).

Penelitian yang membahas tentang pengaruh wilayah dalam kemiskinan rumah tangga pertanian di Indonesia masih belum banyak dilakukan. Mursalina dan Melly (2016) dalam kesimpulannya menyatakan variabel yang signifikan memengaruhi kemiskinan rumah tangga pertanian antara lain variabel umur KRT, status kepemilikan rumah, jumlah anggota rumah tangga, ukuran rumah, sumber air minum, sumber bahan utama memasak, dan kepemilikan sepeda motor. Selanjutnya, penelitian oleh Prayitno (2019) dihasilkan kesimpulan bahwa umur, pendidikan, rasio ketergantungan, kepemilikan lahan, akses kredit, dan kegagalan panen signifikan memengaruhi rumah tangga pertanian berstatus miskin di Indonesia.

Uraian latar belakang di atas mendasari pentingnya melakukan penelitian yang mengkaji hierarki tentang kemiskinan rumah tangga pertanian. Tujuan penelitian antara lain untuk mengetahui variabel pada level rumah tangga maupun level wilayah yang signifikan memengaruhi kemiskinan rumah tangga pertanian di Provinsi Sulawesi Selatan tahun 2020 serta mengetahui variasi wilayah terhadap kemiskinan.

\section{METODE PENELITIAN}

Penelitian ini menggunakan data sekunder berupa data mentah hasil Susenas KOR bulan Maret tahun 2020 serta data yang sudah diolah oleh BPS pada tahun 2020. Terdapat sampel sebanyak 7.088 rumah tangga pertanian dari Provinsi Sulawesi Selatan yang digunakan dalam penelitian. Kemiskinan rumah tangga pertanian merupakan variabel dependen dalam penelitian. Variabel 
independen pada level rumah tangga adalah pendidikan KRT (X1), jenis kelamin KRT (X2), jumlah ART (X3), tipe daerah (X4), kepemilikan lahan (X5), dan akses layanan keuangan (X6), sedangkan pada level wilayah adalah rasio ketergantungan (X7) dan Indeks Pembangunan Manusia (X8).

Analisis inferensia yang digunakan adalah regresi multilevel logistik biner dengan random intercept. Tahapan analisis yang dilakukan dalam penelitian ini adalah sebagai berikut:

1. Melakukan analisis deskriptif kemiskinan rumah tangga pertanian

2. Melakukan pemeriksaan kasus multikolinearitas menggunakan kriteria VIF

3. Pengujian signifikansi random effect

4. Melakukan uji signifikan parameter secara simultan

5. Melakukan uji signifikan parameter secara parsial

6. Penghitungan odds ratio

7. Penghitungan Intraclass Correlation (ICC)

\section{HASIL DAN PEMBAHASAN}

Berdasarkan hasil pengolahan data Susenas Maret 2020, diketahui bahwa terdapat 11,83 persen rumah tangga pertanian di Sulawesi Selatan yang miskin dan 88,17 persen sisanya merupakan rumah tangga pertanian tidak miskin.

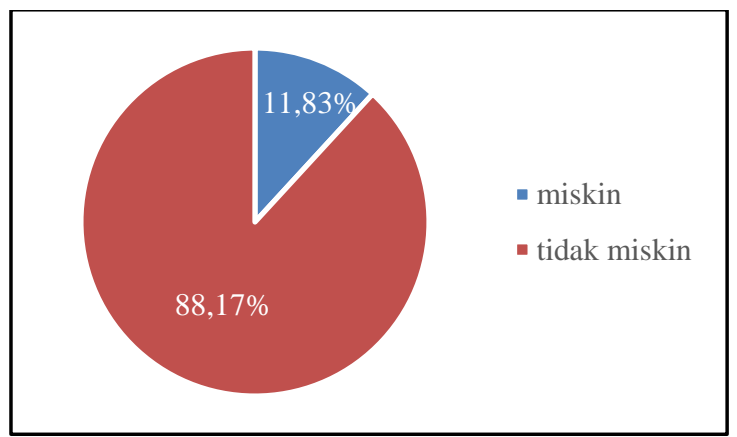

Gambar 1. Persentase kemiskinan rumah tangga pertanian di Sulawesi Selatan

Hasil karakteristik rumah tangga pertanian menurut variabel independen level rumah tangga didapatkan 10,98 persen rumah tangga pertanian miskin tinggal di daerah perdesaan dan 0,84 persen berstatus miskin di daerah perkotaan. Terdapat 10,47 persen rumah tangga pertanian dengan pendidikan tertinggi KRT $\leq$ SMP yang berstatus miskin. Hal yang cukup menarik adalah 9,16 persen rumah tangga pertanian yang memiliki lahan di Sulawesi Selatan berstatus miskin.
Sedangkan, rumah tangga yang tidak memiliki lahan hanya 2,67 persen yang berstatus miskin. Hasil karakteristik rumah tangga pertanian di Provinsi Sulawesi Selatan disajikan secara menyeluruh pada Tabel 1. berikut:

Tabel 1. Karakteristik rumah tangga pertanian

\begin{tabular}{llcc}
\hline \multirow{2}{*}{ Variabel } & Kategori & \multicolumn{2}{c}{ Status Kemiskinan } \\
\cline { 3 - 4 } & & Miskin & $\begin{array}{c}\text { Tidak } \\
\text { Miskin }\end{array}$ \\
\hline Pendidikan & $\leq$ SMP & $10,47 \%$ & $89,53 \%$ \\
KRT & $>$ SMP & $1,36 \%$ & $98,64 \%$ \\
\hline Jenis Kelamin & Perempuan & $2,16 \%$ & $97,84 \%$ \\
KRT & Laki-Laki & $9,66 \%$ & $90,34 \%$ \\
\hline \multirow{2}{*}{ Jumlah ART } & $\leq 4$ & $4,19 \%$ & $95,81 \%$ \\
& $>4$ & $7,64 \%$ & $92,36 \%$ \\
\hline \multirow{2}{*}{ Tipe Daerah } & Perdesaan & $10,98 \%$ & $89,02 \%$ \\
\hline Kepemilikan & Perkotaan & $0,84 \%$ & $99,16 \%$ \\
\hline Lahan & Yidak & $2,67 \%$ & $97,33 \%$ \\
\hline Akses Layanan & Tidak & $10,30 \%$ & $89,70 \%$ \\
Keuangan & Ya & $1,53 \%$ & $98,47 \%$ \\
\hline
\end{tabular}

Sebelum analisis regresi, dilakukan pemeriksaan asumsi multikolinearitas. Hasil pengujian asumsi multikolinearitas disajikan dalam Tabel 2. berikut.

Tabel 2. Pengujian asumsi multikolinearitas

\begin{tabular}{c|cccccc}
\hline Variabel & $\mathrm{X}_{1}$ & $\mathrm{X}_{2}$ & $\mathrm{X}_{3}$ & $\mathrm{X}_{4}$ & $\mathrm{X}_{5}$ & $\mathrm{X}_{6}$ \\
\hline $\mathrm{VIF}$ & 1,02 & 1,02 & 1,03 & 1,03 & 1,01 & 1,03 \\
\hline
\end{tabular}

Berdasarkan Tabel 2. diketahui bahwa seluruh variabel independen memiliki nilai VIF dibawah 10, hal ini menunjukkan tidak adanya multikolinearitas dan dapat dilanjutkan ke analisis regresi.

Dalam analisis regresi, dilakukan pengujian random effect untuk mengetahui kecocokan metode multilevel untuk data yang digunakan dalam penelitian. Pengujian signifikansi random effect menghasilkan nilai Likelihood Ratio Test sebesar 204,47 . Nilai tersebut lebih besar dari $\chi_{0,05 ; 1}^{2}=3,84$ dan dapat diambil kesimpulan adanya random effect yang signifikan dengan tingkat kepercayaan $95 \%$. 
Selain itu, dibandingkan nilai AIC pada kondisi tanpa variabel penjelas (null model) antara model regresi logistik biner satu level dan regresi multilevel. Hasil yang didapat menunjukkan bahwa nilai AIC pada regresi multilevel lebih kecil daripada regresi satu level ketika kondisi tanpa variabel penjelas (null model). Sehingga, regresi multilevel logistik biner lebih baik untuk digunakan dalam menjelaskan data.

Tabel 3. Hasil nilai AIC pada null model

\begin{tabular}{lc}
\hline \multicolumn{1}{c}{ Model } & AIC \\
\hline Regresi satu level & 4758,858 \\
Regresi multilevel & 4556,386 \\
\hline
\end{tabular}

Untuk mengetahui adanya paling sedikit satu variabel independen yang berpengaruh secara signifikan terhadap status kemiskinan rumah tangga pertanian, dilakukan pengujian signifikansi parameter secara simultan. Statistik uji parameter secara simultan diperoleh dengan,

$$
\begin{aligned}
& G=-2 \ln \left(\frac{L \text { (null model })}{L(\text { conditional model })}\right) \\
& =-2(-2276,1932-(2082,4344)) \\
& =387,5176
\end{aligned}
$$

Berdasarkan pengujian parameter secara simultan, diperoleh nilai $G$ yang lebih besar dari $\chi_{0,05 ; 8}^{2}=$ 15,51. Didapatkan kesimpulan bahwa terdapat setidaknya satu variabel independen yang signifikan dalam memengaruhi kemiskinan rumah tangga pertanian di Provinsi Sulawesi Selatan dengan tingkat kepercayaan $95 \%$.

Selain menguji secara simultan, dilakukan uji parsial untuk memperoleh informasi signifikansi dan pengaruh setiap variabel independen terhadap kemiskinan rumah tangga pertanian. Uji parsial menggunakan hipotesis sebagai berikut:

$H_{0}: \beta_{k}=0$

$H_{1}: \beta_{k} \neq 0, k=1,2, \ldots 8$

Tabel 4. menunjukkan hasil statistik uji estimasi parameter secara parsial dalam model regresi random intercept multilevel logistik biner. Terdapat enam variabel pada level rumah tangga dan satu variabel pada level wilayah yang memiliki pengaruh signifikan terhadap kemiskinan rumah tangga pertanian berdasarkan hasil pengujian parameter secara parsial.

Variabel level rumah tangga yang signifikan memengaruhi kemiskinan rumah tangga pertanian antara lain pendidikan KRT, jenis kelamin KRT, jumlah ART, tipe daerah, kepemilikan lahan, dan akses layanan keuangan. Sedangkan pada level kabupaten/kota, variabel IPM signifikan memengaruhi kemiskinan rumah tangga pertanian.

\begin{tabular}{|c|c|c|c|c|}
\hline Variabel & Koefisien & S.E. & $p$-value & $\begin{array}{c}\text { Odds } \\
\text { Ratio }\end{array}$ \\
\hline Konstanta & 5,896 & 4,116 & 0,152 & $\begin{array}{c}363,58 \\
13\end{array}$ \\
\hline $\begin{array}{l}\text { Pendidikan } \\
\text { KRT } \\
>\text { SMP } \\
\leq \text { SMP }\end{array}$ & $-0,637$ & 0,126 & $0,000^{*}$ & 0,529 \\
\hline $\begin{array}{l}\text { Jenis } \\
\text { Kelamin } \\
\text { Laki-laki } \\
\text { Perempuan }\end{array}$ & $-0,498$ & 0,113 & $0,000 *$ & 0,608 \\
\hline $\begin{array}{l}\text { Jumlah } \\
\text { ART } \\
>4 \\
\leq 4\end{array}$ & 1,345 & 0,087 & $0,000 *$ & 3,840 \\
\hline $\begin{array}{l}\text { Tipe } \\
\text { Daerah } \\
\text { Perkotaan } \\
\text { Perdesaan }\end{array}$ & $-0,862$ & 0,156 & $0,000 *$ & 0,422 \\
\hline $\begin{array}{l}\text { Pemilikan } \\
\text { Lahan } \\
\text { Ya } \\
\text { Tidak } \\
\end{array}$ & $-0,634$ & 0,111 & $0,000 *$ & 0,531 \\
\hline $\begin{array}{l}\text { Akses } \\
\text { Layanan } \\
\text { Keuangan } \\
\text { Ya } \\
\text { Tidak } \\
\end{array}$ & $-0,849$ & 0,123 & $0,000 *$ & 0,428 \\
\hline $\begin{array}{l}\text { Rasio } \\
\text { Ketergantu } \\
\text { ngan }\end{array}$ & 0,085 & 0,056 & 0,125 & 1,089 \\
\hline IPM & $-0,167$ & 0,056 & $0,003 *$ & 0,846 \\
\hline
\end{tabular}

Tabel 4. Hasil signifikansi parameter dan odds ratio

Keterangan: * adalah signifikan pada $\alpha=5 \%$

Berdasarkan Tabel 4, dihasilkan persamaan regresi multilevel logistik biner sebagai berikut:

$\ln \left(\frac{\widehat{\pi_{l \jmath}}}{1-\widehat{\pi_{\imath \jmath}}}\right)$

$=5,896-0,637$ pendidikan $_{i j}$

- 0,498 jenis kelamin $i j+1,345$ jumlah $A R T_{i j}$

$-0,862$ tipe daerah $_{i j}-0,634$ lahan $_{i j}$

$-0,849$ akses keuangan $i j$

+ 0,085 Rasio Ketergantungan ${ }_{j}-0,167$ IPM $_{j}$

Berdasarkan hasil pengujian signifikansi secara parsial, seluruh variabel pada level rumah 
tangga signifikan memengaruhi kemiskinan rumah tangga pertanian di Provinsi Sulawesi Selatan. Pendidikan KRT berpengaruh terhadap status kemiskinan dengan nilai koefisien -0,637. Rasio kecenderungan yang diperoleh sebesar 0,529 artinya rumah tangga pertanian dengan KRT yang memiliki pendidikan tertinggi diatas SMP cenderung untuk miskin dibandingkan rumah tangga yang dikepalai oleh KRT dengan pendidikan tertinggi SMP kebawah sebesar 0,529 kali.

Jenis kelamin KRT signifikan dalam berpengaruh terhadap status kemiskinan rumah tangga pertanian. Rasio kecenderungan untuk miskin rumah tangga dengan laki-laki sebagai KRT sebesar 0,608 dibandingkan rumah tangga dengan KRT perempuan. Atau dapat dinyatakan rumah tangga dengan KRT perempuan memiliki kecenderungan lebih besar untuk miskin senilai 1,645 kali dibandingkan rumah tangga yang berjenis kelamin KRT laki-laki.

Selanjutnya, rumah tangga pertanian yang memiliki ART berjumlah lebih dari 4 mempunyai kecenderungan sebesar 3,840 kali untuk berstatus miskin daripada rumah tangga dengan jumlah ART tidak lebih dari 4. Rasio kecenderungan rumah tangga yang tinggal di daerah perkotaan untuk berstatus miskin sebesar 0,422 atau dapat dinyatakan rumah tangga pertanian yang tinggal di perdesaan mempunyai kecenderungan 2,370 kali untuk miskin dibandingkan rumah tangga pertanian yang tinggal di perkotaan.

Rumah tangga pertanian yang memiliki lahan mempunyai rasio kecenderungan 0,531, maka kecenderungan rumah tangga yang tidak memiliki lahan untuk miskin sebesar 1,883 kali dibandingkan rumah tangga dengan status kepemilikan lahan. Sedangkan ditinjau dari akses layanan keuangan, rumah tangga pertanian yang tidak mendapatkan akses layanan keuangan berupa kredit memiliki kecenderungan untuk miskin sebesar 2,336 lebih besar dibandingkan yang mendapat akses layanan keuangan.

Dari variabel kabupaten/kota, ditemukan bahwa variabel Indeks Pembangunan Manusia signifikan memengaruhi status kemiskinan rumah tangga pertanian di Provinsi Sulawesi Selatan. Nilai negatif koefisien IPM menunjukkan bahwa kenaikan nilai IPM berdampak pada kemiskinan rumah tangga pertanian yang semakin berkurang dalam keadaan variabel penjelas lainnya konstan. Sedangkan rasio ketergantungan tidak signifikan memengaruhi kemiskinan rumah tangga pertanian di Provinsi Sulawesi Selatan.

Nilai ICC model regresi multilevel logistik biner yang diperoleh sebesar 0,1156. Yang berarti adanya perbedaan karakteristik antar kabupaten/kota menyebabkan keragaman status kemiskinan rumah tangga pertanian di Provinsi Sulawesi Selatan sebesar 11,56 persen.

\section{KESIMPULAN DAN SARAN}

Kesimpulan yang diperoleh berdasarkan hasil dan pembahasan antara lain terdapat 11,83 persen rumah tangga pertanian berstatus miskin di Sulawesi Selatan tahun 2020. Perbedaan karakteristik antar kabupaten/kota menyebabkan adanya keragaman status kemiskinan rumah tangga pertanian di Provinsi Sulawesi Selatan sebesar 11,56 persen.

Saran bagi penelitian selanjutnya, dapat menggunakan metode spasial serta dapat menambahkan variabel lain yang diduga memengaruhi kemiskinan rumah tangga pertanian.

\section{DAFTAR PUSTAKA}

Badan Pusat Statistik. (2014). Analisis Sosial Ekonomi Petani di Indonesia. Jakarta: BPS.

Badan Pusat Statistik Provinsi Sulawesi Selatan. (2021). Data dan Informasi Kemiskinan Provinsi Sulawesi Selatan 2020. Makassar: BPS.

Badan Pusat Statistik Provinsi Sulawesi Selatan. (2021). Indeks Pembangunan Manusia Provinsi Sulawesi Selatan 2020. Makassar: BPS

Badan Pusat Statistik Provinsi Sulawesi Selatan. (2021). Indikator Pasar Tenaga Kerja Provinsi Sulawesi Selatan 2020. Makassar: BPS.

Harlan, J. (2016). Analisis Multilevel. Depok: Gunadarma.

Hox, J. J. (2010). Multilevel Analysis Techniques and Applications (2nd ed). New York: Routledge.

Jiang, Y., Huang, C., Yin, D., Liang, C., Wang, Y. (2020). Constructing HLM to examine multilevel poverty-contributing factors of farmer households: Why and how?. Plos ONE, 15(1):

e0228032. https://doi.org/10.1371/journal.pone.0228032.

Litbang Pertanian. (2019). Strategi Penanggulangan Kemiskinan di Pertanian dan Perdesaan [Policy Brief]. Jakarta: Badan Litbang Pertanian.

Mursalina \& Melly. (2016). Pengaruh Faktor Sosial-Ekonomi Terhadap Status Kemiskinan Rumah Tangga Pertanian di Aceh. Jurnal Agrisep, 17(2).

Volandio Ardhian Rastantra/

J Statistika Vol. 14, No. 2, (2021) 
J Statistika Vol. 14, No. 2, (2021), Hal. 93-98

Okunola, A. M. \& Ojo, O. S. (2020). Household Poverty Measurement and Its Determinants Among Rural Farmers in Ondo State, Nigeria. Journal Poverty \& Public Policy, 11(4), 277290

Prayitno, H. L. (2019). Kemiskinan Rumah Tangga Pertanian di Indonesia [Skripsi thesis, Universitas Airlangga. UNAIR Repository. http://repository.unair.ac.id/id/eprint/86825.

Volandio Ardhian Rastantra/

J Statistika Vol. 14, No. 2, (2021) 